\title{
Familial association of rheumatoid arthritis and fibrosing alveolitis
}

\author{
R. C. HILTON AND D. A. PITKEATHLY \\ Department of Rheumatology, Wrightington Hospital, Appley Bridge, Lancs.
}

Fibrosing alveolitis (interstitial pulmonary fibrosis) was first described in detail by Hamman and Rich (1944) and familial cases were first published by Peabody, Peabody, Hayes, and Hayes (1950). MacMillan (1951) described the condition in identical twin sisters and Hughes (1964) listed 28 previously reported cases with familial fibrosing alveolitis and added three of his own. Further patients have been reported by Swaye, van Ordstrand, McCormack, and Wolpaw (1969) and Bonanni, Frymoyer, and Jacox (1965).

Fibrosing alveolitis has been reported in 23 children, fourteen of whom were less than 12 months old. Rheumatoid lung disease in children is rare and was first reported by Brinkman and Chaikof (1959).

Familial fibrosing alveolitis with rheumatoid arthritis is even more unusual, the only report being of 63-year-old identical twin sisters (Coltorti, di Simone, Vitale, Scognamillo, 1967).

In view of the rarity of this familial association we felt justified in reporting another family, comprising a father and his six children (Figure).
The serological investigations are detailed in Table I and the pulmonary function studies in Table II (overleaf).

\section{Case reports}

Case 1, a 33-year-old man, first developed joint symptoms in 1962 at the age of 22 years and a diagnosis of rheumatoid arthritis was made. Early in 1968 he developed a cough with slight haemoptysis and 4 weeks later became pyrexial and dyspnoeic. Pneumococci were isolated from the sputum and treatment with penicillin was started. The response was poor and he developed signs of a right

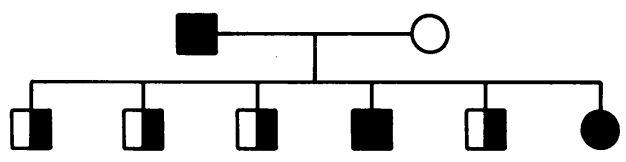

Rhe umatoid arthritis and fibrosing alveolitis Fibrosing alveolitis

FIGURE Pedigree of affected family

Table I Serological investigations

\begin{tabular}{|c|c|c|c|c|c|c|c|c|c|}
\hline Case no. & Sex & $\begin{array}{l}\text { Age } \\
\text { (yrs) }\end{array}$ & $S C A T$ & $\begin{array}{l}\text { Latex } \\
\text { fixation }\end{array}$ & $A N F$ & $\begin{array}{l}L E \\
\text { cells }\end{array}$ & $\begin{array}{l}\text { Thyroid antibodies } \\
\text { 1. Thyroid autoprecipitin test } \\
\text { 2. Thyrotoxic (antimicrosomal) } \\
\text { C-F test } \\
\text { 3. Tanned cell agglutinating } \\
\text { antithyroglobulin titre }\end{array}$ & $\begin{array}{l}\text { Antibodies to liver disease } \\
\text { 1. Complement fixation with } \\
\text { liver mitochondria } \\
\text { 2. Antibody to smooth muscle } \\
\text { (Aluorescent technique) } \\
\text { 3. Antibody to mitochondria } \\
\text { (fluorescent technique) }\end{array}$ & $\begin{array}{l}\text { Antibody to } \\
\text { gastric parietal } \\
\text { cells }\end{array}$ \\
\hline 1 & $\mathbf{M}$ & 33 & $\begin{array}{l}\text { Positive } \\
\text { (256) }\end{array}$ & $\begin{array}{l}\text { Positive } \\
(2,560)\end{array}$ & $\begin{array}{l}\text { Positive } \\
1 / 20\end{array}$ & Negative & Negative & $\begin{array}{l}\text { Antibody to smooth muscle } \\
\text { positive-1/4 } \\
\text { Antibody to mitochondria } \\
\text { positive-1/16 }\end{array}$ & $\begin{array}{l}\text { Positive } \\
1 / 16\end{array}$ \\
\hline 2 & $\mathbf{M}$ & 8 & $\begin{array}{l}\text { Positive } \\
\text { (256) }\end{array}$ & $\begin{array}{l}\text { Positive } \\
(5,120)\end{array}$ & $\begin{array}{l}\text { Positive } \\
1 / 600\end{array}$ & Negative & Negative & Negative & Negative \\
\hline 3 & $\mathbf{F}$ & 6 & Negative & Negative & $\begin{array}{l}\text { Positive } \\
1 / 600\end{array}$ & Positive & - & - & - \\
\hline 5 & $\mathbf{M}$ & 11 & Negative & Negative & $\begin{array}{l}\text { Positive } \\
+++\end{array}$ & - & Negative & Negative & Negative \\
\hline 6 & $\mathbf{M}$ & 10 & Negative & Negative & $\begin{array}{l}\text { Positive } \\
++\end{array}$ & 一 & - & - & - \\
\hline 7 & $\mathbf{M}$ & 9 & Negative & Negative & Negative & - & - & - & - \\
\hline 4 & $\mathbf{M}$ & 7 & Negative & Negative & Negative & - & Negative & $\begin{array}{l}\text { Antibody to smooth muscle } \\
\text { positive-1/4 } \\
\text { Antibody to mitochondria } \\
\text { positive-1/4 }\end{array}$ & Negative \\
\hline
\end{tabular}


Table II Pulmonary function studies

\begin{tabular}{|c|c|c|c|c|c|c|c|c|}
\hline \multirow[b]{2}{*}{ Case no. } & \multirow[b]{2}{*}{$\begin{array}{l}\text { Date of } \\
\text { test }\end{array}$} & \multicolumn{2}{|c|}{ Vital capacity (l.) } & \multirow[b]{2}{*}{$\begin{array}{l}F E V \mid V C \times 100 \\
(\text { per cent. })\end{array}$} & \multirow[b]{2}{*}{$\begin{array}{l}\mathrm{PO}_{2} \\
(\mathrm{~mm} . \mathrm{Hg})\end{array}$} & \multirow[b]{2}{*}{$\begin{array}{l}\mathrm{PCO}_{2} \\
(\mathrm{~mm} . \mathrm{Hg})\end{array}$} & \multicolumn{2}{|c|}{$\begin{array}{l}\text { Transfer factor }(\mathrm{ml} . \\
\mathrm{CO} / \mathrm{min} . / \mathrm{mm} . \mathrm{Hg})\end{array}$} \\
\hline & & Actual & Predicted & & & & Actual & Predicted \\
\hline 1 & $\begin{array}{l}7.4 .71 \\
15.3 .73\end{array}$ & $3 \cdot 0$ & $5 \cdot 0$ & 93 & $\begin{array}{l}75 \\
60\end{array}$ & $\begin{array}{l}34 \\
30\end{array}$ & $\begin{array}{l}18 \cdot 4 \\
14 \cdot 7\end{array}$ & $\begin{array}{l}30 \\
30 \cdot 0\end{array}$ \\
\hline 2 & $\begin{array}{l}7.4 .71 \\
15.3 .73\end{array}$ & $\begin{array}{l}0 \cdot 6 \\
1 \cdot 1\end{array}$ & $\begin{array}{l}1 \cdot 2 \\
1 \cdot 5\end{array}$ & $\begin{array}{l}83 \\
73\end{array}$ & $\begin{array}{l}90 \\
80\end{array}$ & $\begin{array}{l}25 \\
26 \cdot 5\end{array}$ & $6 \cdot 6$ & $14 \cdot 5$ \\
\hline 3 & 15.3 .73 & 0.4 & $1 \cdot 4$ & 87 & 69 & 27 & & \\
\hline 5 & 15.3 .73 & $1 \cdot 5$ & $2 \cdot 1$ & 87 & 58 & $24 \cdot 5$ & $9 \cdot 9$ & $18 \cdot 5$ \\
\hline 4 & & $0 \cdot 4$ & $1 \cdot 0$ & 75 & 79 & $24 \cdot 0$ & & \\
\hline 6 & & 1.6 & $2 \cdot 6$ & 75 & 80 & 30 & $11 \cdot 4$ & $18 \cdot 0$ \\
\hline 7 & & $2 \cdot 3$ & $2 \cdot 3$ & 91 & 81 & 29 & $15 \cdot 6$ & $21 \cdot 0$ \\
\hline
\end{tabular}

pleural effusion which led to admission to hospital. Chest $x$ ray confirmed the presence of the effusion, together with consolidation of the right posterior basal segment and fine mottling throughout both lung fields.

He was first seen in the rheumatology clinic in 1970 because of painful joints and at that time had no chest symptoms.

\section{Examination}

A few inspiratory crepitations were present at the right base. Swelling and limitation of movement were present in many of the small joints of the hands and there was also evidence of inflammatory joint disease in the feet, elbows, and shoulders.

\section{Laboratory investigations}

Haemoglobin $(\mathrm{Hb}) 12.6 \mathrm{~g} / .100 \mathrm{ml}$. White blood count (WBC) $7 \cdot 800 / \mathrm{cmm} . / 100 \mathrm{ml}$. Erythrocyte sedimentation rate (ESR) $50 \mathrm{~mm}$./hr (Westergren). Serum albumin $4 \cdot 2$ g. $/ 100 \mathrm{ml}$. Serum globulin $3.8 \mathrm{~g} . / 100 \mathrm{ml}$. Sheep cell agglutination test (SCAT) positive (256), latex-fixation test (LFT) positive $(2,560)$. Antinuclear factor (ANF) weakly positive $(1 / 20)$. Serum immunoglobulins: IgG $700 \mathrm{mg}$./100 ml., IgM $250 \mathrm{mg}$./100 ml., IgA $290 \mathrm{mg}$./100 $\mathrm{ml}$. Routine urine examination negative. Blood urea normal (38 mg./100 ml.)

\section{$X$ ray appearances}

Chest $x$ ray showed diffuse mottling in both lung fields, which has increased substantially since 1968 .

\section{Pulmonary function tests (Table II)}

The main abnormalities were a reduced transfer factor of $18.4 \mathrm{ml} . \mathrm{CO} / \mathrm{min} . / \mathrm{mm}$. $\mathrm{Hg}$ (predicted normal-30 ml. $\mathrm{CO} / \mathrm{min} . / \mathrm{mm}$. $\mathrm{Hg}$ ), a reduced partial pressure of oxygen $\left(\mathrm{PO}_{2} 75 \mathrm{~mm} . \mathrm{Hg}\right)$ and a reduced carbon dioxide tension $\left(\mathrm{PCO}_{2} 30 \mathrm{~mm} . \mathrm{Hg}\right)$ in arterial blood in the resting state.

\section{Course}

During the past 3 years the rheumatoid arthritis has remained inactive and the patient has had only minimal respiratory symptoms. When recently seen, Schirmer's test for defective lacrimal secretion was positive. A number of additional investigations have been carried out (Table I), the main findings being positive mitochondrial antibodies (1/16) and positive gastric cell antibodies (1/16). Pulmonary function tests were also repeated (Table II) and showed a further reduction in transfer factor $(14.7 \mathrm{ml}$. $\mathrm{CO} / \mathrm{min} . / \mathrm{mm} . \mathrm{Hg}$ ) and a $\mathrm{PO}_{2}$ of $60 \mathrm{~mm} . \mathrm{Hg}$.

Case 2, an 8-year-old boy, the son of Case 1, and the fourth child in a family of six, was first seen in August, 1970, when he gave a 2-year history of intermittent pain in the left groin, swelling of the right foot, pain in the left hand, and loss of weight.

\section{Examination (August 8, 1970)}

He was thin and much underweight, weighing only $29 \mathrm{lb}$. (below 3rd percentile). No cardiovascular or respiratory abnormalities were detected, but there was synovial thickening of the left carpus and right tarsus.

\section{Laboratory investigations}

$\mathrm{Hb} 11.3 \mathrm{~g} . / 100 \mathrm{ml}$. WBC $5.500 / \mathrm{cmm}$. ESR $52 \mathrm{~mm}$. $/ \mathrm{hr}$ (Westergren). SCAT positive $(256)$. LFT positive $(5,120)$. Serum albumin $4.7 \mathrm{~g} . / 100 \mathrm{ml}$. Serum globulin $3.0 \mathrm{~g} . / 100$ $\mathrm{ml}$. ANF negative. LE cells negative. Serum IgG 1,000 mg./100 ml., IgM $145 \mathrm{mg}$./100 ml., IgA $250 \mathrm{mg}$. $/ 100 \mathrm{ml}$.

\section{$X$ ray appearances}

Chest $x$ ray showed diffuse mottling throughout both lung fields.

\section{Pulmonary function tests (Table II)}

The main abnormality was a vital capacity of $600 \mathrm{ml}$. (predicted value 1.2 litres). Transfer factor was not estimated.

\section{Course}

Involvement of other joints developed over the next few months including the metacarpophalangeal and proximal interphalangeal joints of both hands, the subtaloid, and 
the metatarsophalangeal joints. Subcutaneous nodules appeared on both elbows. He is still much under weight (slightly above the 3rd percentile) but his height is less affected (on the 25th percentile). He was treated with chloroquine phosphate $125 \mathrm{mg}$. daily and was later given a short course of gold injections. However, he failed to improve and ACTH 10 units three times per week was commenced in August, 1972. Recent laboratory investigations are shown in Table I, the only new finding being a strongly positive ANF test. Recent pulmonary function tests (Table II) revealed a reduced transfer factor of 6.6 $\mathrm{ml}$. CO/min./mm. $\mathrm{Hg}$ and $\mathrm{PO}_{2}$ of $80 \mathrm{~mm}$. $\mathrm{Hg}$.

Case 3, a 6-year-old girl, daughter of Case 1, and the sixth child in the family, was first brought by her mother to the out-patient clinic in December, 1970, because she was complaining of pain in her feet and left hand. Her mother had also noticed that she was stiff and clumsy in her movements on waking in the morning and her ability to walk had become seriously impaired.

\section{Examination}

She was very small for her age, both her height and weight being well below the 3 rd percentile. Abnormalities were again confined to the locomotor system. There was active synovitis of the right wrist and both knees, and she had a $35^{\circ}$ flexion deformity of the left elbow. A sub-cutaneous nodule was present on the right elbow. There was limitation of the wrist and subtaloid movements and early flexion deformities of the knees.

\section{Laboratory investigations}

Hb $10.3 \mathrm{~g} . / 100 \mathrm{ml}$. WBC 10,000/cmm. ESR $30 \mathrm{~mm}$. $/ \mathrm{hr}$ (Westergren). Serum albumin $4 \cdot 1 \mathrm{~g} . / 100 \mathrm{ml}$. Serum globulin $3 \cdot 1 \mathrm{~g} . / 100 \mathrm{ml}$. SCAT negative (16). LFT negative (80). ANF positive $(1 / 600)$. LE cells positive on two occasions. Serum IgG $1,500 \mathrm{mg}$./100 ml., IgM $58 \mathrm{mg}$./100 $\mathrm{ml}$., IgA $140 \mathrm{mg} . / 100 \mathrm{ml}$.

\section{$X$ ray appearances}

Chest $x$ ray showed diffuse mottling throughout both lung fields.

\section{Course}

She was admitted to hospital and treated with rest and splintage. The flexion deformities of the knees were corrected and salicylate therapy was instituted. The arthritis went into remission and she has remained in fairly good health. The RF tests (Table I) are still negative but the ANF remains positive. Pulmonary function tests(Table II) carried out recently for the first time, show a vital capacity of $400 \mathrm{ml}$. (predicted value 1 litre) but estimations of transfer factor were not done.

Case 4, a 7-year-old boy, the son of Case 1, and the fifth child in the family, is symptom free.

\section{Examination}

He is much under weight, below the 3 rd percentile $(37 \mathrm{lb}$.), and of short stature, on the 10th percentile (45").

\section{Laboratory investigations}

Hb 12.5 g. $/ 100 \mathrm{ml}$. WBC $5,200 / \mathrm{cmm}$. ESR $25 \mathrm{~mm}$. $/ \mathrm{hr}$ (Westergren). SCAT negative (4). LFT negative $(<40)$.
IgG $1,100 \mathrm{mg} . / 100 \mathrm{ml}$., IgM $54 \mathrm{mg} . / 100 \mathrm{ml}$, IgA 210 mg./100 ml.

\section{$X$ ray appearances}

Chest $x$ ray showed widespread mottling throughout both lung fields

\section{Pulmonary function tests (Table II)}

The main abnormality was a reduction in vital capacity $(400 \mathrm{ml}$.), the predicted value being $1,400 \mathrm{ml}$.

Case 5, an 11-year-old boy, the son of Case 1, is symptom free.

\section{Examination}

$\mathrm{He}$ is underweight (below the 3rd percentile), but of average height (50th percentile). No abnormalities were present in the viscera or joints.

\section{Laboratory investigations}

Hb $14.3 \mathrm{~g} . / 100 \mathrm{ml}$. WBC $4,300 / \mathrm{cmm}$. ESR $4 \mathrm{~mm}$. $/ \mathrm{hr}$ (Westergren). SCAT and LFT negative. ANF strongly positive. IgG $1,800 \mathrm{mg}$. $/ 100 \mathrm{ml}$., IgM $90 \mathrm{mg}$./100 ml., IgA $300 \mathrm{mg} . / 100 \mathrm{ml}$.

\section{$X$ ray appearances}

Chest $x$ ray showed a little increase in fine reticulation.

\section{Pulmonary function tests}

The main abnormalities were a transfer factor of $9.9 \mathrm{ml}$. $\mathrm{CO} / \mathrm{min} . / \mathrm{mm}$. $\mathrm{Hg}$ (predicted value $18.5 \mathrm{ml} . \mathrm{CO} / \mathrm{min} . / \mathrm{mm}$. $\mathrm{Hg}$ ), a vital capacity of $1,500 \mathrm{ml}$. (predicted value 2,100 $\mathrm{ml}$.), and a $\mathrm{PO}_{2}$ of $58 \mathrm{~mm}$. $\mathrm{Hg}$.

Case 6, a 10-year-old boy, son of Case 1, is symptom free.

\section{Examination}

$\mathrm{He}$ is underweight and is on the $3 \mathrm{rd}$ percentile $(56 \mathrm{lb}$.) but his height is less affected, being on the 25 th percentile (52"). No abnormalities were found in the viscera or joints.

\section{Laboratory investigations}

Hb 12.8 g. $/ 100 \mathrm{ml}$., WBC $5,300 / \mathrm{cmm}$. SCAT negative. LFT negative. ANF positive. IgG $1,600 \mathrm{mg}$. $/ 100 \mathrm{ml}$., IgM $90 \mathrm{mg} . / 100 \mathrm{ml}$., IgA $380 \mathrm{mg}$. $/ 100 \mathrm{ml}$.

\section{$X$ ray appearances}

Chest $x$ ray normal.

\section{Pulmonary function tests}

The main abnormalities were a transfer factor of $11.4 \mathrm{ml}$. $\mathrm{CO} / \mathrm{min} . / \mathrm{mm}$. $\mathrm{Hg}$ (predicted value $18.0 \mathrm{ml}$. $\mathrm{CO} / \mathrm{min}$./ $\mathrm{mm} . / \mathrm{Hg}$ ) and a vital capacity of $1,600 \mathrm{ml}$. (predicted value $2,600 \mathrm{ml}$.).

Case 7, a 9-year-old boy, son of Case 1, is symptom free.

\section{Examination}

He is of normal stature and no abnormalities were found in the viscera or joints.

\section{Laboratory investigations}

Hb 12 g. $/ 100 \mathrm{ml}$. WBC 5,600/cmm. ESR $8 \mathrm{~mm}$. $/ \mathrm{hr}$ (Westergren). SCAT, LFT, and ANF negative. IgG 1,800 mg./100 ml., IgM 96 mg./100 ml., IgA 130 mg./100 ml. 
$X$ ray appearances

Chest $x$ ray normal.

\section{Pulmonary function tests}

The only abnormality was a reduced transfer factor of $15.6 \mathrm{ml}$. CO/min. $/ \mathrm{mm}$. $\mathrm{Hg}$ (predicted value $21.0 \mathrm{ml}$. $\mathrm{CO} / \mathrm{min} . / \mathrm{mm}$. $\mathrm{Hg}$ ).

\section{Discussion}

It could be argued that fibrosing alveolitis and rheumatoid arthritis have occurred in this family as a chance association, but this seems unlikely in view of the rarity of familial cases of either disease and the well-recognized occurrence of fibrosing alveolitis in patients with rheumatoid disease.

Rheumatoid lung disease was first reported by Ellman and Ball (1948) and, although many cases have been reported in adults, it is rare in children. Usually it is associated with strongly positive rheumatoid factor tests and this finding is uncommon in children with juvenile polyarthritis. Brinkman and Chaikof (1959) reported a patient whose chest $x$ ray showed scattered areas of infiltration when she was 6 years old. Rheumatoid arthritis developed 4 years later and soon afterwards she became increasingly dyspnoeic and died of pulmonary insufficiency when 15 years old. Post mortem examination confirmed the presence of fibrosing alveolitis. Jordan and Snyder (1964) reported a girl who developed rheumatoid arthritis when 7 years old and $3 \frac{1}{2}$ years later became increasingly dyspnoeic. A lung biopsy confirmed the diagnosis of fibrosing alveolitis and 6 months later she died as a result of the pulmonary disease. Both these children were seropositive when they developed lung disease and they are the only two children with rheumatoid lung disease to have been reported in the English literature. Of our three patients with both disorders, two are strongly seropositive but the youngest (Case 3) has always been seronegative. Tomasi, Fudenberg, and Finby (1962) emphasized the frequency of pulmonary involvement in rheumatoid patients having high titres of rheumatoid factors. They also pointed out that positive rheumatoid factors may be present in patients with fibrosing alveolitis in the absence of joint manifestations.

Four of the children in our family study have no joint symptoms but the pulmonary function tests suggest the presence of fibrosing alveolitis. In two this is supported by abnormal chest $x$ rays. All four are seronegative for rheumatoid factors but three have a positive ANF test and this finding is also present in the father and two children with rheumatoid arthritis and fibrosing alveolitis, although the father is only weakly positive and both he and Case 2 were negative on first testing. Turner-Warwick and Doniach (1965) found that the incidence of ANF in rheumatoid patients with lung involvement did not exceed that obtained in an unselected rheumatoid population. However, in patients with fibrosing alveolitis alone, they found a higher incidence of ANF than in controls although the titres were lower than in systemic lupus erythematosus.

Case 3 differs from her father and brother in having negative RF tests but positive LE cell tests. No other features of systemic lupus erythematosus have been found in this child or in other members of the family. This same patient has had a nodule on her left elbow. Bywaters, Glynn, and Zeldis (1958) reported subcutaneous nodules in twelve patients with Still's disease, six of whom were seronegative. They did, however, point out that in this group the RF tests were more frequently positive than in patients with Still's disease without nodules.

The original cases of fibrosing alveolitis described by Hamman and Rich were much more acute than many of those reported later (Hughes, 1964). A subacute or chronic course is more frequent, and it has been postulated (Scadding, 1960; Hughes, 1964) that these may represent varying reactions to one or more aetiological agents. Several authors have suggested that the earlier the onset of fibrosing alveolitis, the worse the prognosis, although a child described by Swaye (1969) was still well 4 years after the diagnosis was made at the age of $3 \frac{1}{2}$ years.

Progressive fibrosing alveolitis in childhood is rare. Of 24 cases found in the English literature, fifteen were less than 12 months old when diagnosed and the majority died within 12 months. Both Case 2 and Case 3 have been known to have lung changes for 3 years and both remain symptomless. The father (Case 1) developed a probable pneumococcal pneumonia in 1968 but since then has had only a slight cough and no dyspnoea. Although his chest $x$ ray has deteriorated since 1968 the pulmonary functions tests have changed very little. Despite the absence of symptoms the father and all his children have evidence of pulmonary disease. The transfer factor is impaired in five members of the family and of these four have a reduced vital capacity and two a reduced $\mathrm{PO}_{2}$. The other two (Cases 3 and 4) have a reduced vital capacity. Four of the children have abnormal chest $x$ rays. As all the patients are symptomless it was felt that further investigation was not justified. In the absence of chronic airways disease, the abnormal pulmonary function tests suggest that these patients belong to the heterogeneous group of patients described with fibrosing alveolitis. Donohue, Laski, Uchida, and Munn (1959) reported the first cases of familial fibrosing alveolitis and suggested that such cases may form a clinical and pathological entity which can be identified separately because of the definite genetic transmission. Hughes (1964) found only 31 familial cases in the literature and six of these had radiological changes before overt symptoms. It is, therefore, important to take a careful family history 
and to $x$ ray the relatives if familial fibrosing alveolitis is suspected.

The inheritance of fibrosing alveolitis is now considered to be autosomal dominant (Swaye, 1964), although when the first familial cases were reported a sex-linked dominant inheritance was considered because of the lack of father to son transmission.

Regarding genetic studies of rheumatoid arthritis, Lawrence and Ball (1958) found that this disease occurred four times as commonly in first-degree relatives of patients with severe rheumatoid arthritis as in a control population. However, there is not yet any conclusive proof of genetic transmission, as the familial clustering could be equally well explained by other aetiological mechanisms (Blumberg, 1960).

A family study of Still's disease (Ansell, Bywaters, and Lawrence 1962) showed radiological evidence of erosive arthritis in the hands to be four times as frequent in female relatives than in controls. Other findings were an increased incidence of sacroiliitis in male relatives and a less frequently positive sheep cell agglutination test than in controls.

Turner-Warwick and Doniach (1965) found no increased incidence of organ-specific antibodies in patients with pulmonary fibrosis. Of our patients, Cases 1 and 4 both had positive tests for mitochondrial and smooth muscle antibodies and in addition Case 1 had a positive test for antibody to gastric parietal cells.

Steroids, in the form of ACTH, have been given to one patient (Case 2) because of joint symptoms. These symptoms improved but therapy for 8 months has produced no improvement in the pulmonary function studies.

\section{Summary}

A family with rheumatoid arthritis and fibrosing alveolitis is described. Three members, two of whom were children, presented with rheumatoid arthritis and the chest $x$ ray appearances were compatible with the presence of fibrosing alveolitis. Four other members were asymptomatic but were found to have evidence of pulmonary disease when investigated.

We wish to thank Dr. S. S. Chatterjee, consultant chest physician, Baguley Hospital, Manchester for arranging the pulmonary function studies.

\section{References}

Ansell, B. M., Bywaters, E. G. L., And Lawrence, J. S. (1962) Ann. rheum. Dis., 21, 243 (A family study in Still's disease)

BLUMBERG, B. S. (1960) Arthr. and Rheum., 3, 178 (Genetics and rheumatoid arthritis)

Bonanni, P. P., Frymoyer, J. W., AND JACox, R. F. (1965) Amer. J. Med., 39, 411 (A family study of idiopathic pulmonary fibrosis. A possible dysproteinemic and genetically determined disease)

Brinkman, G. L., AND Chaikof, L. (1959) Amer. Rev. resp. Dis., 80, 732 (Rheumatoid lung disease. Report of a case which developed in childhood)

Bywaters, E. G. L., GlynN, L. E., AND Zeldis, A. (1958) Ann. rheum. Dis., 17, 278 (Subcutaneous nodules of Still's disease)

Coltorti, M., di Simone, A., Vitale, P., and Scognamillo, A. (1967) Policlinico, Sez. Med., 74, 8 (Rheumatoid arthritis with diffuse interstitial pulmonary fibrosis in two apparently monocharionic twin sisters)

Donohưe, W. L., LASKI, B., UChIDA, I., AND MúN, J. D. (1959) Pediatrics, 24, 786 (Familial fibrocystic pulmonary dysplasia and its relation to the Hamman-Rich syndrome)

Ellman, P., AND BALl, R. E. (1948) Brit. med.J., 2, 816 ('Rheumatoid disease' with joint and pulmonary manifestations)

Hamman, L., AND Rich, A. R. (1944) Bull. Johns Hopk. Hosp., 74, 177 (Acute diffuse interstitial fibrosis of the lungs)

HuGHES, E. W. (1964) Thorax, 19, 515 (Familial interstitial pulmonary fibrosis)

Jordan, J. D., AND Snyder, C. H. (1964) Amer.J. Dis. Child., 108, 174 (Rheumatoid disease of the lung and cor pulmonale)

LaWrence, J. S., AND Ball, J. (1958) Ann. rheum. Dis., 17, 160 (Genetic studies on rheumatoid arthritis)

MacMillan, J. M. (1951) Dis. Chest, 20, 426 (Familial pulmonary fibrosis)

Peabody, J. W., Peabody, J. W., Jr., Hayes, E. W., and Hayes, E. W., Jr. (1950) Ibid., 18, 330 (Idiopathic pulmonary fibrosis; its occurrence in identical twin sisters)

Scadding, J. G. (1960) Brit. med. J., 1, 443 (Chronic diffuse interstitial fibrosis of the lungs)

Swaye, P., van Ordstrand, H. S., McCormack, L. J., and Wolpaw, S. E. (1969) Dis. Chest, 55,7 (Familial Hamman-Rich syndrome)

Tomasi, T. B., Fudenberg, H. H., AND Finby, N. (1962) Amer. J. Med., 33, 243 (Possible relationship of rheumatoid factors and pulmonary disease)

Turner-Warwick, M., AND DoniaCh, D. (1965) Brit. med.J., 1, 886 (Auto-antibody studies in interstitial pulmonary fibrosis) 